\title{
Trophic structure of the benthic invertebrate community in the littoral zone of a mountain cascade system
}

\author{
Mirosława Prus, Paweł Bijok and Tadeusz Prus
}

Prus, M., Bijok, P. and Prus, T. 2002. Trophic structure of the benthic invertebrate community in the littoral zone of a mountain cascade system. - Web Ecol. 3: 12-19.

\begin{abstract}
The cascade of Solina/Myczkowce dam reservoirs situated in the West Carpathian Mts was investigated. The cascade consists of two reservoirs, the upper one built $35 \mathrm{yr}$ ago on the San and Solinka Rivers of 2100 ha area separated from another one, of 190 ha area, with hypolimnion cold water supplied from the upper one.

The offshore zone was investigated monthly ( 6 sites of upper, 3 sites of lower reservoir) using a tube bottom sampler. Besides numbers, biomass and biodiversity indices, the proportion of predators, plant/detritus-feeders and filter-feeders was assessed.

In upper reservoir Solina, with a lack of filter-feeders, a clear preponderance of plantdetritus feeders was observed. Predators, consisting mostly of leeches and hydranchnellids were present. In lower reservoir Myczkowce, all three trophic classes were present in the first year of study in almost equal proportions and in 1998 with slight preponderance of plant/detritus feeders was observed.

The Oligochaeta/Chironomidae index in both reservoirs was low, indicating low degree of eutrophication. Only one site in Solina reservoir (near a fish culture) and one in Myczkowce (influenced by tourist activity) showed a high value of this index.
\end{abstract}

M.Prus (mce-pan@mail.unicom.pl), P. Bijok and T. Prus, International Centre of Ecology, Polish Academy of Sciences, Dziekanów Leśny near Warsaw, PL-05-092 Eomianki, Poland.

The cascade consisting of two dam reservoirs SolinaMyczkowce has been constructed on the River San in the 1960s. The first fragmentary hydrobiological studies were started in the 1970s (Pasternak 1973, Starmach et al. 1976). Further investigations on chemical properties of water, N:P ratio, species composition and abundance of zooplankton and profundal benthos in Solina reservoir were carried out at the end of 1980s (Płużański et al. 1990).

The first assessment of species composition and numbers of species of the invertebrate fauna in the littoral zone has been done recently (Prus et al. 1999). This pertained to the problem of the biodiversity characteristics of these res- ervoirs. From these data, an analysis was made of the trophic structure of identified species or taxonomic groups. The mode of feeding was used to classify organisms into trophic classes. In the non-predatory class, animals feeding on living or dead particles of organic matter were included: numerous groups of Chironomidae larvae (both mining and benthic), Nematoda, some Trichoptera and also Crustacea (Asellus, Gammarus). This class was named plant-detritus feeders. In the predatory class were included organisms swallowing their prey as a whole (numerous species of Hirudinea, some Trichoptera, Chironomidae, Coleoptera, Megaloptera (Sialis) and Chaoborus), or partitioning their prey (some Trichoptera), or sucking 
up their prey such as Heteroptera, some Hirudinea and some Coleoptera. The third class consisted of filter feeders: Bivalvia and Ostracoda, distinguished as a very important group because of its role in the process of filtrating of seston (Kajak 1998).

In the light of extensive investigations over the past three years (involving primary production, phytoplankton, zooplankton, littoral and profundal invertebrate fauna, broaded by studies of ichthyofauna) the elaboration of trophic structure in the benthic fauna of inshore zone seems to be of crucial importance for the trophic web modelling. This will serve for the estimation of the biocenosis structure and for establishing backgrounds against which future changes may be assessed. This will lead to the assessment of changes caused by pollution, for example from aquaculture or intensive development of tourist centers.

Trophic interactions are not static phenomena but dynamic. Thus, for most ecological systems, they should be examined with spatial and temporal aspects included (Wiens et al. 1986, Giller and Gee 1987). By definition, the limits of environment result from trophic relationships. However, for a lake or a pond, the spatial organisation in a water body (profundal, littoral, pelagic zones) has a substantial effect on functioning of trophic web. The same holds for the temporal scale - trophic relationships are estimated for one time point and summed up for longer periods (Warren 1989).

Many authors suggested that high numbers of Oligochaeta are the effect of excessive pollution of water (e.g. Howmiller and Beeton 1971, Aston 1973, Nutall and Purves 1974). High abundance of this group is associated with great adaptive abilities to live at low concentrations of oxygen verging on anaerobic conditions (Aston 1973). The Oligochaeta/Chironomidae index can be used to estimate the degree of pollution in various parts of reservoirs or to compare different water bodies.

The present paper aimed at the assessment of the trophic structure of invertebrate benthic fauna in the littoral zone of Solina-Myczkowce cascade. The analysis covers to two years of study. It is the first approach to such subjects in dam reservoirs, where physical conditions for the development of a littoral zone are harsh, mainly due to changeability of water. An additional aim is to assertain the possible differences in the eutrophication of separate parts or sites of Solina and Myczkowce dam reservoirs.

\section{Materials and methods}

Hydrological data were given in detail in an earlier paper (Prus et al. 1999). Sampling sites in both reservoirs are given in Fig. 1. In 1997 and in 1998, three sampling sites were chosen in the littoral zone of Myczkowce reservoir. The first was near the flat, open, unforested northeast shore; the second one was near the forested southwest shore situated at the foot of the steep slopes of Berdo mountain (covered with mixed forests), hardly accessible to tourists; and a third one was situated on the forested north shore, near a small boat pier. In 1997 four sites were chosen in the Solina reservoir. Two sites were situated along the former Solinka river bed: Nelson Bay, close to the dam, and Hazel Bay in the middle of this part of the river. Two other sites were along the former course of the San river bed, Cold Bay and Snake Bay. Both were characteristic of the less polluted part of the dam reservoir. All four sites were located on shores covered with forest and exposed to water erosion. In 1998 two additional sites were investigated. One on the Solinka River section: Solinka mouth (near fish cages, ca $700 \mathrm{~m}$ after the river discharge) and another one, along San river section: San mouth (near tourist village, ca $1000 \mathrm{~m}$ after the river discharge). In addition, two sampling sites were chosen within the courses of San and Solinka rivers.

Sampling started in July 1997 and was performed monthly until October 1997. In 1998 samples were taken from May and performed monthly until October. At each site, 10 quantitative samples were taken from the depth of

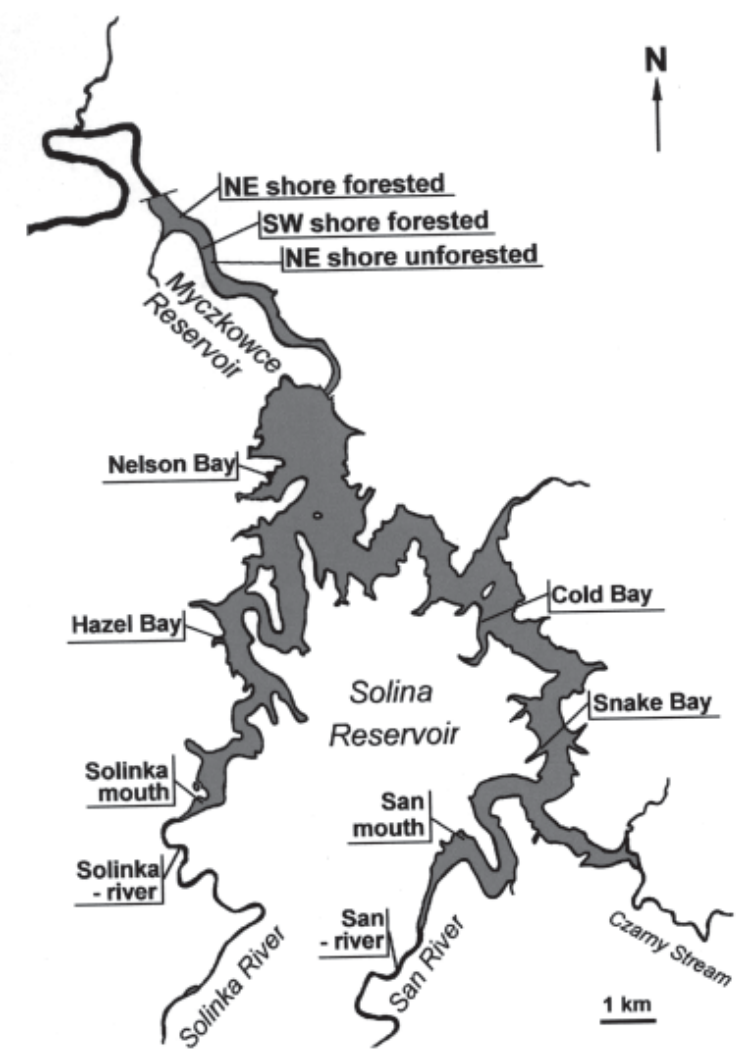

Fig. 1. Sampling sites in littoral of the two dam reservoirs. 
1.5-2.0 m (at random) using a cylindrical bottom sampler (Morduchaj-Boltovski type). Samples were brought to laboratory, kept at a temperature of $\mathrm{ca} 4^{\circ} \mathrm{C}$ and successively searched for invertebrates. The animals were identified to species or higher taxonomic group. The list of species is given in Prus et al. (1999).

\section{Results}

Collected in vivo animals were identified as belonging to the taxonomic groups listed in Table 2. Based on published data, groups have been classified into larger units according to the prevailing mode of feeding of their representatives. Three feeding classes were distinguished: filter feeders, plant-detritus feeders and predators (Table 1). There were 2 groups of filter feeders, 8 of plant and detritus feeders and 12 of predators.

In the Myczkowce reservoir, all taxonomic groups belonging to three trophic classes were present. In 1998, the share of filter feeders decreased in favour of plant detritus feeders (Fig. 2). The Solina reservoir was analysed in two separate sections: the Solinka river section and the San river section. They showed a high degree of similarity. In the Solina reservoir, filter feeders are practically absent in the littoral zone. Predators were represented mainly by leeches and Hydrachnellae, the other groups being collected in small numbers (Figs 3 and 4). When comparing the two sampling sites established in the rivers in 1998 it can be seen that in Solinka River only plant-detritus feeders occur, whereas in the San River both predators and plant detritus feeders are found.

Proportions among the trophic classes show that in the Solina reservoir, with a lack of filter feeders, a clear preponderance of plant-detritus feeders is observed. Thus this community can be considered as not fully developed. In the Myczkowce reservoir, where all trophic classes were present at almost equal proportions in 1997 and with a slight preponderance of plant-detritus feeders in 1998, the benthic community is fully developed.

Another subject approached in this study is the estimation of trophication of the cascade system by using Oligochaeta/Chironomidae index. Inferring from this index it can be concluded that the trophication of both reservoirs is rather low with some exceptions (Fig. 5).

In the Myczkowce reservoir, trophication is high in one site, due to tourist activity.

In the Solina reservoir (Fig. 6) the Solinka river section (being more subject to pollution from fish cages and heavy tourism activity) showed a higher index than the San river section (more natural environment, mainly forested shores).

Table 1. Trophic classes for rivers and reservoirs.

\begin{tabular}{|c|c|c|c|c|c|}
\hline \multirow[t]{2}{*}{ Class } & \multirow[t]{2}{*}{ Group } & \multicolumn{2}{|c|}{ Rivers } & \multicolumn{2}{|c|}{ Reservoirs } \\
\hline & & Solinka & San & Myczkowce & Solina \\
\hline & Turbelaria & - & - & + & + \\
\hline \multirow{11}{*}{ (12 groups) } & Hirudinea & - & + & ++++ & + \\
\hline & Plecoptera & - & + & - & + \\
\hline & Anisoptera & - & - & - & - \\
\hline & Megaloptera & - & - & +++ & - \\
\hline & Coleoptera & - & - & + & - \\
\hline & Heteroptera & - & + & + & + \\
\hline & Chaoboridae & - & - & + & - \\
\hline & Heleidae & - & + & ++ & + \\
\hline & Stylaria & - & - & +++ & - \\
\hline & Pelopiine & - & + & + & + \\
\hline & Hydrachnellae & - & + & +++ & + \\
\hline Plant-detritus & Oligochaeta & + & + & ++++ & ++ \\
\hline feeders & Isopoda & - & - & +++ & - \\
\hline \multirow[t]{6}{*}{ (8 groups) } & Amphipoda & - & - & + & - \\
\hline & Ephemeroptera & + & + & + & ++ \\
\hline & Trichpotera & - & + & +++ & ++ \\
\hline & Chironomidae & + & + & +++ & +++ \\
\hline & Culicidae & + & + & + & + \\
\hline & Gastropoda & - & + & +++ & + \\
\hline Filter feeders & Ostracoda & - & - & +++ & + \\
\hline (2 groups) & Bivalvia & - & - & ++++ & - \\
\hline
\end{tabular}


Table 2. Comparison of Ohle index in some dam reservoirs in Poland.

\begin{tabular}{llcrr}
\hline Type & Dam reservoir & Drainage basin area $\left(\mathrm{km}^{2}\right)$ & Reservoir area $\left(\mathrm{km}^{2}\right)$ & Ohle index \\
\hline Mountainous & Solina & 1174.5 & 21.05 & 56.0 \\
& Myczkowce & 73.5 & 1.91 & 38.5 \\
& Myczkowce & $1248.0 *$ & 1.91 & $653.4 *$ \\
Lowland & Dobczyce & 780.0 & 9.70 & 80.4 \\
& Zegrze & 103600.0 & 33.00 & 3000.0 \\
& Włocławek & 171000.0 & 75.00 & 2280.0 \\
\hline
\end{tabular}

* including Solina drainage basin.

Fig. 2. Proportions of the trophic classes (filled bars: predators, opened bars: plant-detritus feeders, hatched bars: filter-feeders) in littoral invertebrate fauna of the Myczkowce dam reservoir at three sampling sites.
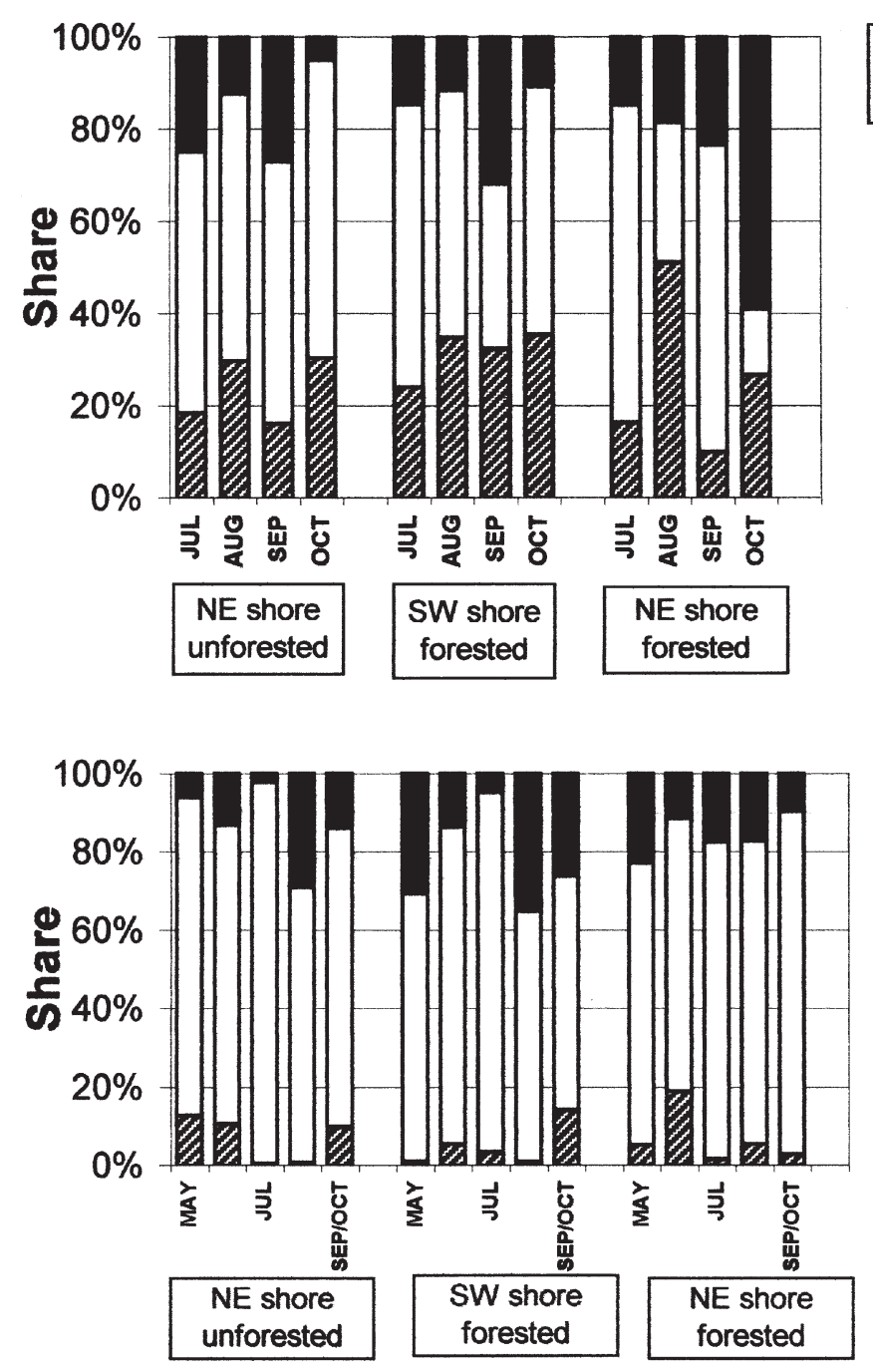


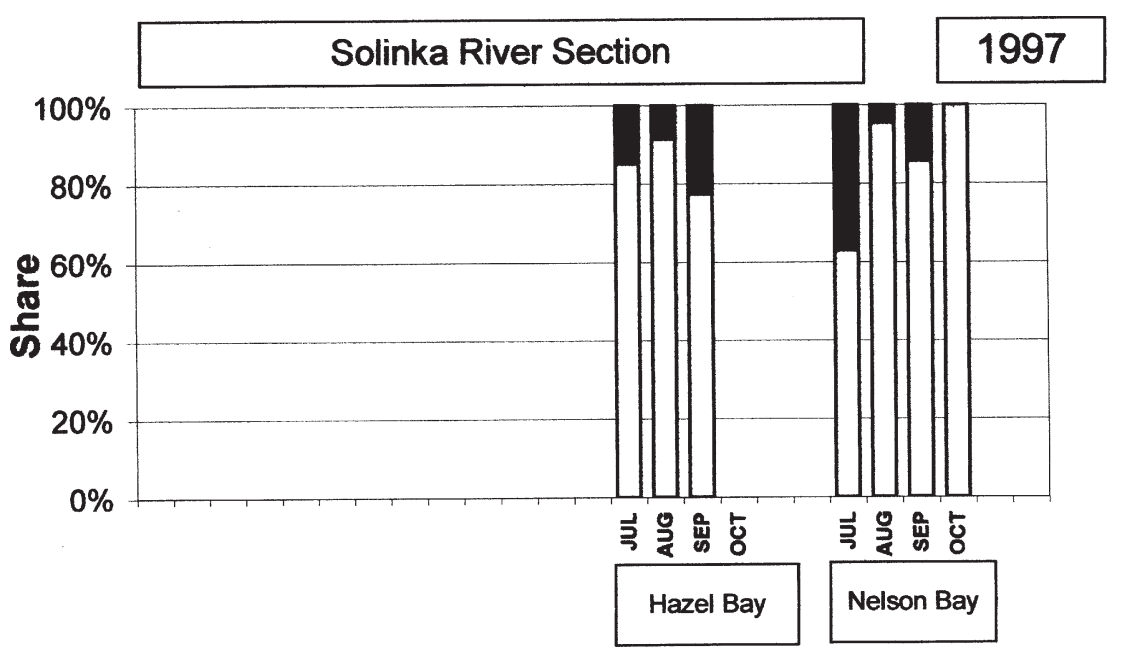

Fig. 3. Proportions of the trophic classes (opened bars: predators, filled bars: plant-detritus feeders) in littoral invertebrate fauna of the Solina dam reservoir at four sampling sites.

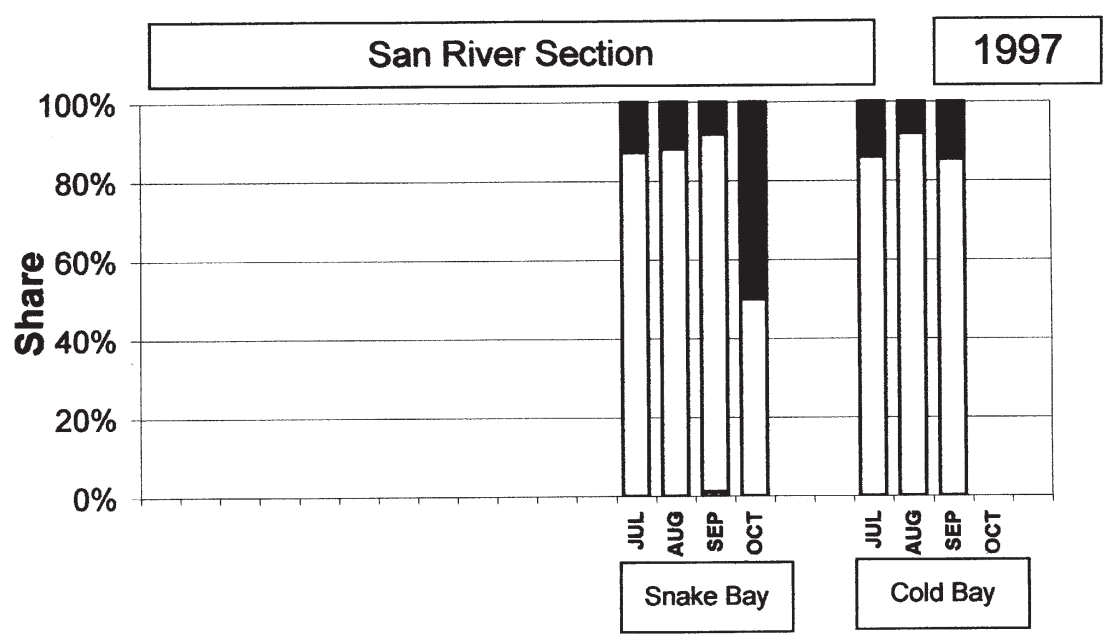

\section{Discussion}

Differences in trophic structure between two dam reservoirs were caused by completely different abiotic conditions. In the Solina dam reservoir the water level changes were very great: up to $10 \mathrm{~m}$. It caused periodic destruction of littoral communities which are restored every spring. Additionally, a strong erosion of steep shores together with heavy loads of clay, brought into dam from rivers in early spring or during rainy periods time during the vegetation season (e.g. large flood in 1997 in Poland), induced a high sedimentation of fine particles. According to Gopal (1994) and Nairn et al. (1995), this is the main stressing factor for littoral organisms. It is also reflected in the numbers and biomass of invertebrate benthic fauna, and their biodiversity in this reservoir. In addition, the macrophytic cover in this zone is very sparse and it is represented only by Myriophyllum spicatum (L.). The invertebrates are com- posed of not more than 7 taxonomic groups with dominance of oligochaetes and chironomids.

The ichthyofauna was estimated for the years 19881990, based on anglers' reports. According to Bieniarz and Epler (1993), the species composition is not rich. In Solina reservoir there occurred roach, bream ( $40 \%$ of angler's catches), and carassius (0.6\%). Of predators, pike-perch (3.6\%), pike (only 0.4 ) and perch (17.3\%). The share of the latter increased from year to year in this reservoir. In Solina, carp and eel were caught sporadically. Because of the time lapse and the less reliable data on ichthyofauna it is difficult to infer anything about relationship between zoobenthos and the fish community.

In the Myczkowce reservoir, the littoral zone has developed typically as for shallow lakes. It is feasible due to small oscillations of water level (up to $2 \mathrm{~m}$ ) and good development of the euphotic zone (the visibility of Secci-disc is up to $3 \mathrm{~m}$ ). These oscillations have a short-term character (di- 
Fig. 4. Proportions of the trophic classes (opened bars: predators, filled bars: plant-detritus feeders) in littoral invertebrate fauna of the Solina dam reservoir at six sampling sites and in the rivers San and Solinka.
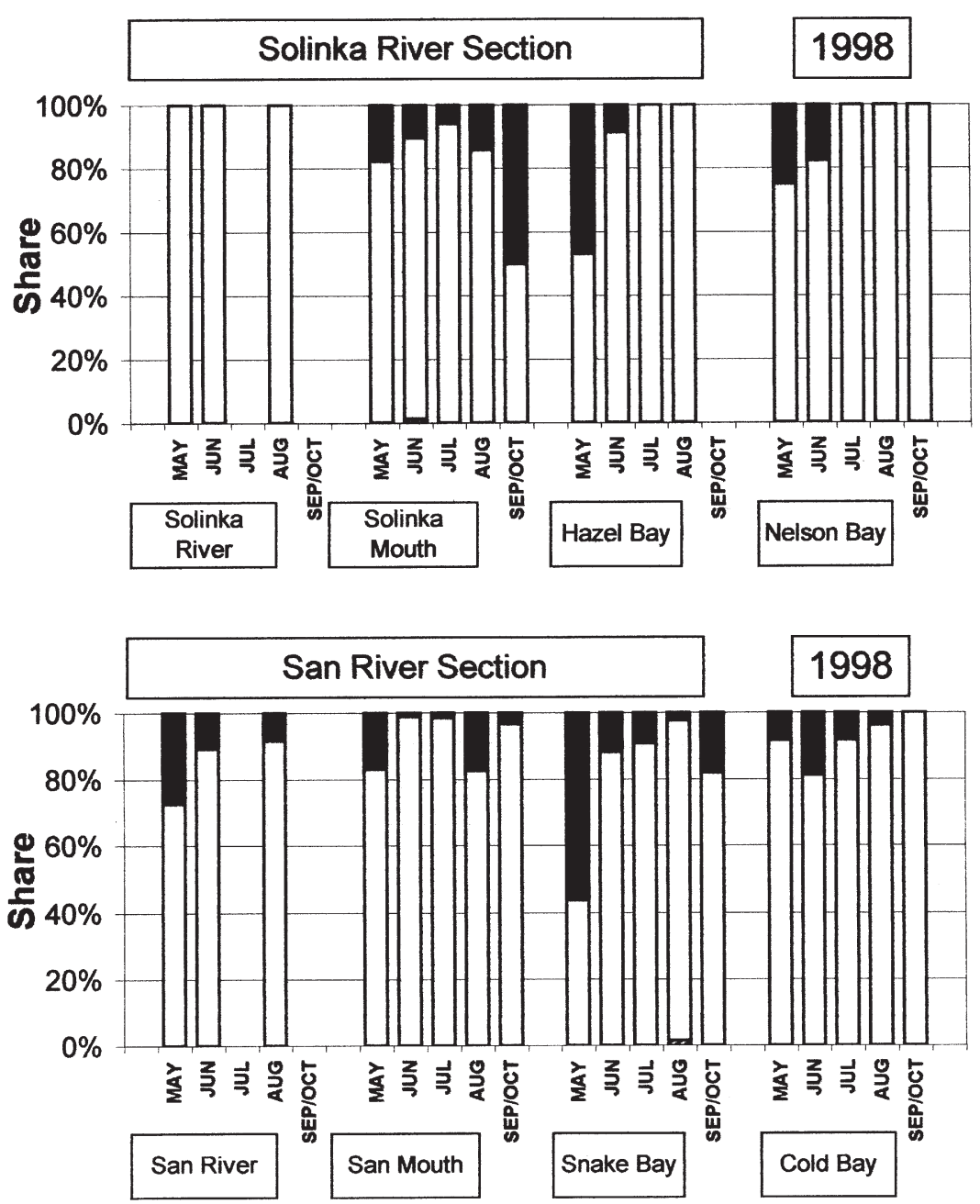

urnal), therefore it does not cause a serious destruction of which is due to non-typically low water temperature, especially in summer, when the reservoir receives large quantities of cold water from the hypolimnion of Solina. The temperature difference between the two reservoirs exceeds $10^{\circ} \mathrm{C}$ in summer. Fast water flow (exchange rate: 120 times $\mathrm{yr}^{-1}$ ) through this water body assures good mixing and aeration. The macrophytic cover is well developed, consisting of Elodea canadensis (Rich), Myriophyllum specatum (L.) and Potamogeton crispus (L.). Such conditions also provide complete trophic structure, although this structure differs among years. The information about fish species living in this reservoir is completely lacking. From anglers' report it is known that this structure is almost similar to that of Solina reservoir.

The difference between the trophic relationships of these two reservoirs arises also from different development of the shore line. When the measured shore line length (b) is related to the circumference of the circle, which surface area is equal to that of the reservoir $(\mathrm{P})$, one receives an index of shore-line development (Kajak 1998). After calculating this index according to the formula: $\mathrm{b}=\mathrm{Rw}$ e find its value for Solina is 9.2 and for Myczkowce 4.1. Thus, the Solina shoreline is twice as developed as that of Myczkowce. However, this does not have much bearing on development of macrobenthos since it is also reversely affected by high water changes and proportion of drainage basin to reservoir area - Ohle index (Kajak 1998) (Table 2). It is evident that this ratio for Solina reservoir is more than ten times lower than for the Myczkowce reservoir. This may seem suprising but one has to take into account the fact that all the water of Solina passes through the Myczkowce reservoir. Thus, the drainage of this reservoir is the sum of the two components in cascade. The high ratio in Myczkowce reservoir explains the proliferous development of macrobenthos in littoral zone. 

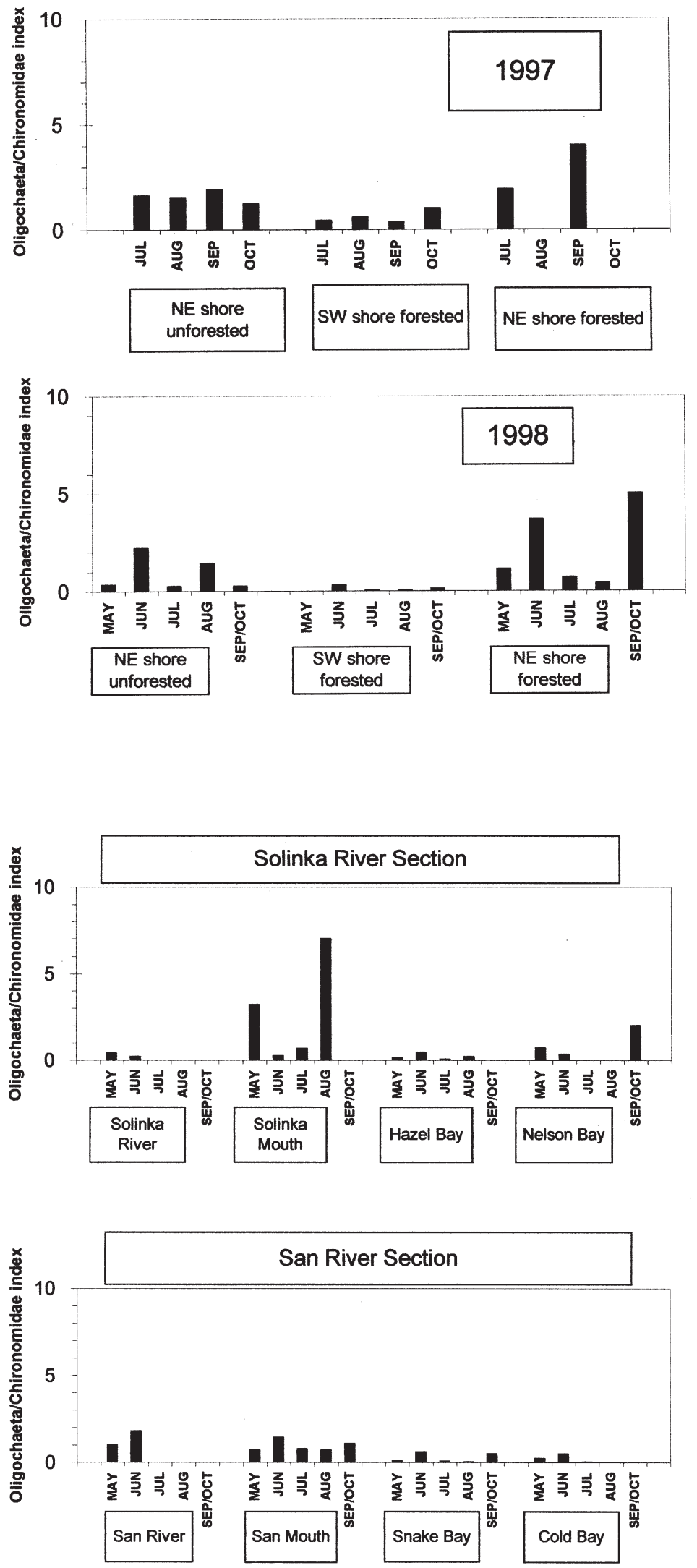

Fig. 5. Oligochaeta/Chironomidae ratio in littoral of the Myczkowce dam reservoir.
Fig. 6. Oligochaeta/Chironomidae ratio in littoral of the Solina dam reservoir and in its main tributaries. 
While the Ohle index in mountainous regions is $<100$, in lowland reservoirs (e.g. Zegrze or Włocławek) it reaches several thousand, indicating highly eutrophic conditions (cf. Table 2).

The cascade plays an important and multi-purpose role in the this region. It is responsible for electric power generation, flood control, household and industrial use of water and tourist activity. In such a situation, learning about the symptoms of excessive eutrophication is very important. The Oligochaeta/Chironomidae index is generally low in both reservoirs, but some sites are exceptions. For Solina reservoir such an exception is the site located near fish cages and in the vicinity of a camping centre. The latter holds also for Myczkowce reservoir. Similar conclusions have also been reported when the proximity of a large town and its tourist impact increased the eutrophication of a nearby part of the mesotrophic lake Wigry in north-eastern part of Poland (Prus 1998).

By and large, when comparing these two reservoirs, the contemporary hypothesis, about the usefulness of building up many rather small dam reservoirs instead of few big ones, is an adequate approach to the problem of water retention.

\section{References}

Aston, R. J. 1973. Tubificids and water quality: a review. - Environ. Pollut. 5: 1-10.

Bieniarz, K. and Epler, P. 1993. Połowy wędkarskie na Solińskim zbiorniku zaporowym. (Fish catching by anglers in the Solina dam reservoir). - Roczniki Naukowe PZW 6: 5-18.

Giller, P. S. and Gee, J. H. R. 1987. The analysis of community organisation: the influence of equilibrium scale and terminology. - In: Gee, J. H. R. and Giller, P. S. (eds), Organisation of communities past and present. 27th Symp. Brit. Ecol. Soc., Blackwell, Oxford, pp. 519-542.

Gopal, B. 1994. The role of ecotones (transition zones) in the conservation and management of tropical inland waters. Inland waters of tropical Asia and Australia conservation and management. - Schweizerbart Verl. Stuttgart, pp. 17-25.
Howmiller, R. P. and Beeeton, A. S. M. 1971. Biological evaluation of environmental quality, Green Bay, Lake Michigan. J. Water Pollut. Control. Fed. 43: 123-133.

Kajak, Z. 1998. Hydrobiologia-Limnologia. Ekosystemy wód śródlądowych. (Hydrobiology-Limnology. Freshwater ecosystems). - Warszawa PWN.

Nairn, R. B. et al. 1995. Artificial beeches as shoreline treatment. - Lake-reserve Manage. 11: 174-175.

Nutall, P. M. and Purves, J. B. 1974. Numerical indices applied to the results of a survey of the macro-invertebrate fauna of the Tamar catchment (southwest England). - Freshwater Biol. 4: 213-222

Pasternak, K. 1973. Rozprzestrzenianie metali ciężkich w wodach płynących w rejonie występowania naturalnych złóż oraz przemysłu cynku i ołowiu. (Expansion of heavy metals in running waters in the region of occurrence of natural ledges and lead and zinc industry). - Acta Hydrobiol. 15: 131245.

Płużański, A. T. et al. 1990. Charakterystyka limnologiczna zbiorników kaskady Górnego Sanu (Solina, Myczkowce). (Limnological characteristics of Upper San cascade reservoirs (Solina, Myczkowce)). - In: Kajak, Z. (ed.), Funkcjonowanie ekosystemów wodnych, ich ochrona i rekultywacja. Część I - Ekologia zbiorników zaporowych i rzek. (Functioning of aquatic ecosystems, protection and recultivation. Part I Ecology of dam reservoirs and rivers). - SGGW-AR, Warszawa 50: 254-281.

Prus, T. 1998. Characteristics of macrofauna in profundal zone of Wigry Lake. - Pol. Arch. Hydrobiol. 45: 35-44.

Prus, T., Prus, M. and Bijok, P. 1999. Diversity of invertebrate fauna in littoral of shallow Myczkowce dam reservoir in comparison with a deep Solina dam reservoir. - Hydrobiologia 408/409: 203-210.

Starmach, K., Wróbel, S. and Pasternak, K. 1976. Hydrobiologia, Limnologia. - PWN, Warszawa.

Warren, P. H. 1989. Spatial and temporal variation in the structure of a freshwater food web. - Oikos 55: 299-311.

Wiens, J. A. et al. 1986. The importance of spatial and temporal scale in ecological investigations. - In: Diamond, J. and Case, T. J. (eds), Community ecology. Harper and Row, pp. $145-153$. 